\title{
Conservation of agriculture land based on local wisdom in Serang Village Purbalingga Regency
}

\author{
Mahal Nungki Enggar Triastoningtias \\ Master of Environmental Sciences, Graduate School, Gadjah Mada University, Yogyakarta, Indonesia [+62 85311349826]
}

\section{Article Info:}

Received: 22 - 12 - 2020

Accepted: 31 - 08 - 2021

\section{Keywords:}

Agriculture land, conservation, local wisdom, pranoto mongso, land management

Corresponding Author: Mahal Nungki ET

Master of Environmental Sciences, Graduate School, Gadjah Mada University; Tel. +6285311349826 Email:

mnungkienggar@gmail.com; mnungkienggar@gmail.ugm.ac.id

\begin{abstract}
Encroachment of forest areas can cause many problems when the management does not pay attention to conservation rules. Forest encroachment is increasingly widespread and is of particular concern to the Serang Village Government, thus encouraging agricultural systems based on local wisdom owned by the community. The study is able to record known land conservation practice, among others, (1) pranoto mongso; (2) nyabuk gunung; (3) sacralize water sources (Festival Tuk Sikopyah); (4) resting agricultural land; (5) using traditional agricultural tools; and (6) Agroforestry. The highest conservation practice is using traditional agricultural equipment by 99\%, nyabuk gunung and forecasting water sources by $96 \%$. While conservation practices are rarely carried out, namely $61 \%$ of agricultural land. Agriculture in Serang Village can be developed because it has large land resources and large market demand. Suitable agricultural land conservation strategies are implemented in the management of sustainable agricultural land in Serang Village, namely (1) preserving local wisdom owned by the community and applied in agricultural land management activities; (2) utilize assistance from the village, district, and central governments to manage and increase agricultural production; (3) increase market distribution and utilize access to transportation; (4) increase cultivation land with available land for increased agricultural production; (5) maintain product quality and create customer satisfaction; and (6) cooperation with the distribution channel to expand the market.
\end{abstract}

How to cite (CSE Style $8^{\text {th }}$ Edition):

Triastoningtias MNE. 2021. Conservation of agriculture land based on local wisdom in Serang Village Purbalingga Regency. JPSL 11(3): 419-429. http://dx.doi.org/10.29244/jpsl.11.3.419-429.

\section{INTRODUCTION}

Encroachment of forest areas into agricultural areas in Indonesia every year continues to increase. Over time, there has been an enormous increase in forest cover loss in Indonesia. FAO research in 1990 showed that forest cover in Indonesia had been reduced from 74\% to 56\%, it happened within 30-40 years (Sunderlin and Resosudarmo, 1997). The latest data from the Ministry of Environment and Forestry totals Indonesia's forest area of 124 million hectares. From 2010 to 2015, Indonesia ranked second highest globally with an average forest loss of 684000 hectares (ha) annually caused by mining and agricultural activities. Sardjono (1998) stated that the cause of high forest encroachment is the motivation of farmers to own land in protected areas (tenure). The rise of forest encroachment is due to the lack of synchronization of programs between the forestry sector and the development of food crops and horticulture aimed to benefit the community's welfare around protected forests (Andri, 2012). Tamba (2020) explained that forest and land resources, as natural resources 
that are important for a life, need to be appropriately managed in order to benefit the community while maintaining its continuity of function and ability. Land management is done rationally accompanied by environmental conservation efforts by including the wider community. This is intended so that the utilization of natural resources does not cause disruption and damage to ecosystems that trigger environmental damage.

The increasingly widespread encroachment of forests is particularly concerned to the Purbalingga Regency Government and the Serang Village Government. This is marked by the enactment of Regional Regulation No. 5 of 2011 on Spatial Plan of Purbalingga Regency Region 2011-2031. It reviews and analyzes related to the change in the use of forest areas into other designations. The encroachment of forest areas does not guarantee the improvement of the welfare of the surrounding community. Until now, Serang Village has been included in the category of red zone (poor zone) in Purbalingga Regency. Forest encroachment triggers an increase in surface flows that play a role in environmental damage. The impact of forest encroachment into agricultural land can cause environmental damage and affect the life system of local people. Serang Village Government began to develop an agricultural system based on local wisdom owned by the community and agrotourism to improve the community's economy while maintaining environmental sustainability.

Local wisdom was first revealed by Wales (1951) refers to local wisdom as "local genius" which means a number of cultures that have the characteristics and are owned by the community as a result of past experiences. Local wisdom is a culture owned by certain communities and certain places that are considered able to survive in the face of globalization, and this is because local wisdom contains values that can be a means of building the character of the nation (Yunus, 2012). Negara (2011) explains that local wisdom is not only about people's knowledge of humans and how good relations are between humans but also concerns human knowledge and understanding with nature and how the relationship between all, where all knowledge is lived, practiced, taught and passed from one generation to the next. Local wisdom in the community is very much in its kind and form. According to Aulia and Dharmawan (2010), local wisdom in society can be values, norms, beliefs, and special rules in society. Local wisdom is built naturally in a community to adapt to the surrounding environment; this behavior develops into a culture in an area and will develop hereditary (Yudana et al., 2015). Local wisdom is required in other meanings as a symbol of spirit in development (Bakar, 2011). Local wisdom is a system in social life, politics, culture, economy, and environment that lives in the midst of local communities. An inherent feature of local wisdom is its dynamic, sustainable, and acceptable nature to its community (Thamrin, 2013). Sumarni and Amirudin (2014) explained that local wisdom is local knowledge used by the community to survive in an environment that is integrated with belief systems, norms, cultures and expressed in traditions and myths embraced over a long period of time.

Land conservation activities based on local wisdom in Serang Village one of them is carried out with the development of Serang Asri Valley (D'LAS) attack based on local wisdom of the community. The development of Serang Asri Valley (D'LAS) can help overcome the community's economic problems, open up employment opportunities, preserve a hereditary culture, and minimize environmental damage. Chasanah et al. (2017) explained that the development and development of the tourism sector could positively influence society and the environment both directly and indirectly. In line with what Nugraha et al. (2020) expressed that local wisdom applied in some areas and practiced properly and earnestly will become the norm, ethics, and morals that lead the community to be more concerned and responsible for the surrounding environment. Modernization and technological advances cause some people to switch to using modern agricultural tools to manage agricultural land because it is considered more practical and saves time. Regarding the application of local wisdom of the community in managing land is not as intensive as it used to be, thus encouraging researchers to review related to the conservation of agricultural land based on local wisdom of the community in managing land in Serang Village. This research aims to 1) know the conservation practices based on local wisdom conducted by the community in managing agricultural land in Serang Village, 2) knowing the factors that affect the community in conducting local wisdom-based agricultural land conservation practices in managing land in Serang Village, and 3) developing a local wisdom based agricultural land conservation strategy that is appropriately applied in the management of agricultural land in Serang Village. 


\section{METHOD}

\section{Research Location}

This research was conducted in November 2020 in Serang Village, Karangreja Subdistrict, Purbalingga Regency. Serang Village has 2878390 ha, consisting of 1245.04 ha of moorland (dry land farming), 174.55 ha of residential land, 1630.52 ha of forest land 2.80 ha of land for other allotments. Geographically Serang Village is located at an altitude of 1650 masl with the lowest temperature reaching $16^{\circ} \mathrm{C}$ and the highest temperature up to $28^{\circ} \mathrm{C}$ with sloping topography and having fertile soil because it is located on the slopes of the volcano. Administratively Serang Village has a boundary west of Kutabawa Village, east of Tlahab Lor Village, south of Sangkanayu Village, and north of Slamet Mount. More details related to the administrative boundaries of Serang Village can be seen in Figure 1.

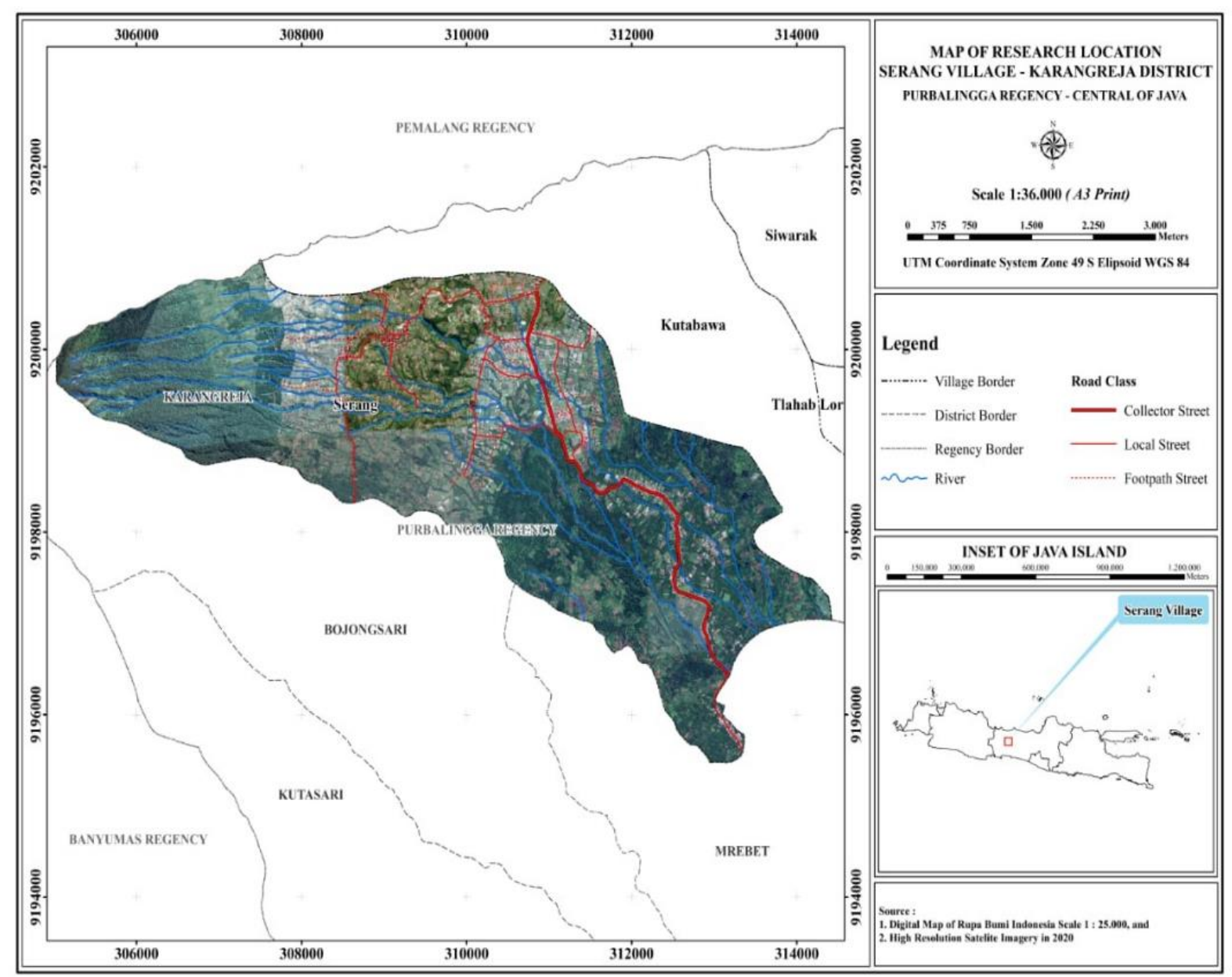

Figure 1 Map of research locations

\section{Data Collection Methods}

The data required in this study consists of primary data and secondary data. Secondary data needed in this study include geographical conditions in Purbalingga Regency, population number, environmental conditions, socio-economic conditions of the community in general in Purbalingga Regency, and problems in the community in general in Serang Village and Purbalingga Regency. The data can be obtained from the Head of Serang Village Office, BPS Purbalingga Regency, Purbalingga Regency Environment Office, Purbalingga Regency Social Service, Bappelitbangda Purbalingga Regency as well as several related agencies in Purbalingga Regency. The required primary and secondary data are tailored to the purpose of the study. To 
review conservation based on local wisdom of the community in managing land in Serang Village, some supporting data obtained from respondent interview results is needed. Determination of the number of samples using the calculation of the formula Slovin with a margin of error used $10 \%$. The Slovin formula is used to calculate the minimum number of samples taken from the population but can represent the entire population. In more detail, the Slovin formula is as follows:

Information:

$$
\mathrm{n}=\frac{\mathrm{N}}{1+\mathrm{Ne}^{2}} \times 100 \%
$$

$n$ : Number of respondent

$e:$ The limit/error rate (in this case used is 0.1 or $10 \%$ )

$\mathrm{N}$ : Population

Based on calculations using the Slovin formula, the number of samples taken as many as 97 respondents and rounded to 100 respondents conducted randomly against people who work as farmers in Serang Village. A sampling of each hamlet is carried proportionally because the land management system has similarities in each hamlet and homogeneity in terms of samples. According to Martono (2010), the criteria for sampling are focused on people who know or have competence with research objectives.

\section{Data Analysis Methods}

The analysis in this study uses quantitative descriptive analysis of the data that has been collected. Quantitative descriptive analysis is used to identify the application of conservation based on local wisdom of the community in managing land in Serang Village. The determination of conservative and not conservative categories of farmers uses the average value of the survey results in the field. If the number of scores $>$ from the average value falls into the conservative category, while the < score of the average value is in the nonconservative category. Conservative farmers hold fast to the old ways of managing agricultural land or can also be called farmers who still maintain local wisdom that is owned for generations in managing agricultural land. While non-conservative farmers are farmers who mostly use modern tools in managing agricultural land and begin to leave local wisdom in managing agricultural land owned for generations. Furthermore, to find out the factors that affect land conservation-based on local wisdom applied by farmers are tested using multiple linear regression.

The analysis results will be used to formulate conservation strategies based on local wisdom that are appropriately applied in Serang Village. Formulation of management strategies based on SWOT. SWOT analysis is a strategic planning technique that evaluating a management system's strengths and weaknesses, opportunities, and threats from the analysis obtained conclusions and conservation strategies based on local wisdom that are appropriate to be applied from a management system that is being carried out.

Strategy decisions need to be considered internal factors that include strengths and weaknesses as well as external factors that include opportunities and threats (Rangkuti, 2006) as described in Table 1. The formulation of strategies need to maximize the role of strength factors and the utilization of opportunities to minimize weaknesses and reduce the impact of threats that arise (Robinson, 1997).

Table 1 Matrix (strength, opportunities, weakness, threats) SWOT

\begin{tabular}{ccc}
\hline Matrix SWOT & Strength (S) & Weakness (W) \\
\hline Opportunities (O) & $\begin{array}{c}\text { Strategies that use power to take } \\
\text { advantage of opportunities (SO) }\end{array}$ & $\begin{array}{c}\text { Strategies that eliminate weaknesses to } \\
\text { take advantage of opportunities (WO) }\end{array}$ \\
\hline Threats (T) & $\begin{array}{c}\text { Strategies that use force to address } \\
\text { threats (ST) }\end{array}$ & $\begin{array}{c}\text { Strategies that eliminate weaknesses } \\
\text { and avoid threats (WT) }\end{array}$ \\
\hline
\end{tabular}

Source: Freddy Rangkuti, 2006 


\section{RESULT AND DISCUSSION}

\section{Conservation of Agricultural Land Based on Local Wisdom of Serang Village Farmers}

Negara (2011) explains that local wisdom is not only about people's knowledge of humans and how good relations are between humans, but also concerns human knowledge and understanding with nature and how the relationship between all, where all knowledge is lived, practiced, taught and passed from one generation to the next. Local wisdom in the community is very much in its kind and form. According to Aulia and Dharmawan (2010) local wisdom in society can be from values, norms, beliefs, and special rules in society. Various local wisdom functions including (1) conservation and preservation of natural resources; (2) developing human resources; (3) the development of culture and science; and (4) instructions on advice, beliefs, literature, and abstinence in society. The community has the same right and the widest and widest to play an active role in the protection and management of the environment, one of which plays a role in developing and maintaining local culture and wisdom in the framework of the preservation of environmental functions (UU No. 32 of 2009).

Local wisdom in the community is related to many things, one of which is related to the conservation of land managed by the community. Serang village is one of the villages that still upholds the values and norms of local wisdom in the community. The people of Serang Village uphold the values, norms, and special rules in the community that until now are still carried out, adhered to, and maintained. It aims to maintain the sustainability of water sources, prevent soil damage, and regulate the management of natural resources in people's lives. Local wisdom in the community related to the conservation of natural resources can be in the form of values practiced in rituals, and traditional ceremonies, and noble norms agreed by the community. The study results related to the type of agricultural land conservation based on local wisdom can be seen in Table 2.

The research results, as in table 2 appear some of the local wisdom that remains preserved by the people of Serang Village for environmental sustainability until future generations. Based on the results of research from 100 farmers who were sampled in the study obtained data. Among others, 63\% of farmers are still guided by pranoto mongso in conducting their agricultural activities. Pranoto mongso is local wisdom passed down through the generations to determine the right time in doing farming business. Although the weather is now relatively challenging to forecast and use as a guideline, farmers still try to use pranoto mongso as a guideline for the farming business.

Table 2 Types of conservation based on local wisdom of Serang Village Community

\begin{tabular}{lccc}
\hline No & Types of Conservation & $\begin{array}{r}\text { Frequency } \\
\text { (f) }\end{array}$ & Percentage (\%) \\
\hline 1 & Pranoto Mongso & 63 & 63 \\
\hline 2 & Nyabuk Gunung & 96 & 96 \\
\hline 3 & Water Source (Festival Tuk Sikopyah) & 96 & 96 \\
\hline 4 & Clearing Farmland (Bero) & 61 & 61 \\
\hline 5 & Using Traditional Farming Tools & 99 & 99 \\
\hline 6 & Wanatani (Agroforestry) & 79 & 79 \\
\hline
\end{tabular}

Source: primary data, 2020

As many as $96 \%$ of the community applies mountain farming and water sources (Tuk Sikopyah festival). Moreover, supported by the topographic conditions of Serang Village, which is hilly, it would be better if the planting pattern is made with the mountain to minimize erosion and landslides. Serang Village farmers also partially still apply "Bero" system, which is $61 \%$ of farmers apply "Bero" system in their planting cycle. It aims to restore soil fertility before replanting. Furthermore, 99\% of farmers use traditional agricultural tools in cultivating their land. This is because it is cheaper in terms of cost and easy because of the hilly topography, making it difficult to use modern agricultural tools such as tractors. To increase the agricultural income of 
serang village farmers, also apply the pattern of agricultural agriculture (agroforestry), from the results of the analysis, it is known that $79 \%$ of farmers use agroforestry planting patterns by mixing annual crops with hardwood. It aims to reduce erosion and increase soil fertility from ecological aspects. In contrast, from the economic aspect of agroforestry agricultural systems, communities can increase agricultural income to meet family needs.

\section{Land Conservation Factors Based on Local Wisdom of Serang Village Farmers}

Local communities have local knowledge related to ecology, agriculture, and forestry that are formed for generations in managing natural resources from generation to generation (Hilmanto, 2009). The concept of local wisdom includes several things, including local knowledge, local intelligence (local genius), local wisdom, and local traditions (local culture) (Siswadi and Purwaneni, 2011). The characteristics of local wisdom in each region vary according to the environmental and cultural conditions of the community. Local wisdom in certain communities can be a form of natural resource management as a local regulatory system that emerged through the history and long adaptation of the community (Oktaviani and Dharmawan, 2010).

All farmers do not fully implement local wisdom-based land conservation in Serang Village. Several factors can affect farmers and become a trigger for farmers to start leaving local wisdom that is already owned for generations in the community. Based on the analysis results, the category of farmers in local wisdom-based land conservation can be known by using the analysis of maximum value and minimum value that will be sought middle value and used as a reference in determining the category of farmers. Based on the calculation results, a minimum value of 17 and a maximum of 28 while for the average value of 22.5 .

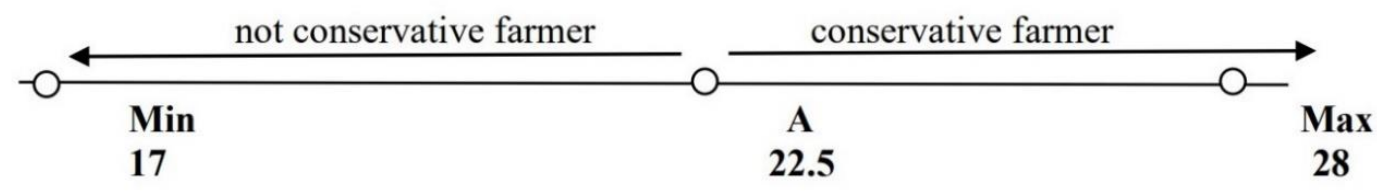

Information:

Min = Minimum

Max = Maksimum

A $=$ Average

$\mathrm{N}<\mathrm{A}=$ Not conservative farmer

$\mathrm{N}>\mathrm{A}=$ Conservative farmer

The measurement results as shown in the figure, are obtained the lower limit (min) of 17, the upper limit ( $\max )$ of 28, and the average value of 22.5. Based on the results of calculations, the score of the field survey is known to be below the average value in the category of non-conservative farmers, while for the score above the average value in the category of conservative farmers. The results of calculations such as those presented in Figure 2 obtained a value of $34 \%$ of farmers in the category of not conservative and $66 \%$ of farmers in the conservative category. The dominant farmers of Serang Village fall into the conservative category because farmers are still strong in maintaining the values of local wisdom in every agricultural activity. This is in line with Niman (2019) stated that the high level of public knowledge about environmental management and conservation is always related to the strong values of local wisdom owned by the community.

Local wisdom is very useful for the people of Serang Village because it is a living knowledge as well as a community guideline in preserving the environment. Along with the progress of the times and technological developments, the development paradigm based on local wisdom is often and begins to be abandoned by the community, especially the younger generation who began to get educated and work outside their home regions. Social and cultural values embraced and used as guidelines for a long time by rural communities became lost (Hamidi, 2002). This also happened in Serang Village. The younger generation who began to get educated and work far from their places of origin gradually began to forget the local wisdom in the community. This is a 
concern of elders, religious leaders, and residents of Serang Village. The community hopes that the younger generation will continue to preserve local wisdom that has been passed down through the community.

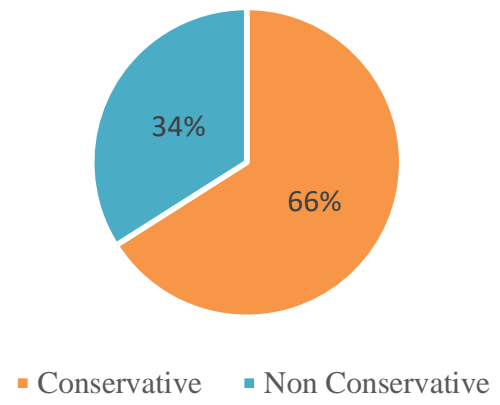

Figure 2 Categories of farmers Serang Village

Factors that affect land conservation based on local wisdom applied by farmers are tested using multiple linear regressions. In regression testing, there are two variables, namely dependent variables, which are influenced by independent variables. In this case, land conservation is based on local wisdom as a dependent variable (Y). The age of farmers, long farming, education, and land ownership are independent variables (X), which will affect variable $\mathrm{Y}$. The linear regression model doubles with the variables used are as follows:

$$
Y=20.543-0.041 X_{1}+0.133 X_{2}-0.148 X_{3}-0.00356 X_{4}
$$

Where:

Y : Local wisdom based land conservation

a : Constant

$\mathrm{b}_{1}$ : Regression coefficient of X1

$\mathrm{b}_{2}$ : Regression coefficient of X2

$b_{3}$ : Regression coefficient of X3

$\mathrm{b}_{4}$ : Regression coefficient of X4

$\mathrm{X}_{1}$ : Age of farmer

$\mathrm{X}_{2}$ : Long farming

$\mathrm{X}_{3}$ : Education

$\mathrm{X}_{4}$ : Land ownership

Based on multiple linear regression testing obtained the results of significance values for the influence of farmer age variables (X1), long farming (X2), education (X3), and land ownership (X4) simultaneously against variable $\mathrm{Y}$ of $0.000<0.05$ and the value of $\mathrm{F}$ calculated 8.173 greater than $\mathrm{F}$ table 2.698 so that it can be concluded that there is an influence of farmer age variables (X1), long farming (X2), education (X3) and land ownership (X4) simultaneously against variable Y. Of the four factors known that a very significant factor affects conservation based on local wisdom applied by farmers is the factor of long farming with a significance value of $0.001<0.05$ which means there is a significant influence on variable $\mathrm{Y}$, while the factor of age of farmers, education and land ownership does not have a significant effect on variable $Y$, but simultaneously the four factors affect simultaneously on variable $Y$. The coefficient of determination from this regression analy sis is 0.256 which means that variable $\mathrm{x}$ has a simultaneous effect on variable $\mathrm{Y}$ by $25.6 \%$.

The old variable of farming becomes a very influential factor there is land conservation applied by farmers, this is because the majority of Serang Village farmers are senior farmers where their farming period has been over 10 years. Since long ago the farmers of Serang Village have always applied local wisdom in cultivating their agricultural land one of them is by making terracing on sloping land and the use of traditional agricultural tools and always upholding the value of gotong-royong between farmers in cultivating land. This 
was studied by farmers for generations since long ago, which aims to conserve their agricultural land and preserve local wisdom owned. People realize that the largest livelihoods of the agricultural sector so that the land must be managed properly in order to continue to produce optimal crop yields to meet their needs.

\section{Community Local Wisdom Based Conservation Strategies}

A strategy is a tool used to achieve goals (Rangkuti, 1997). The formulation of land conservation strategies based on the local wisdom of the farming community in Serang Village produces several variables that will be analyzed to obtain appropriate management alternatives based on internal and external factors. SWOT analysis is based on logic by maximizing internal factors, namely strengths and opportunities, but also minimizes external factors, namely weaknesses and threats. The results of identifying factors of strengths and weaknesses owned by a community can be used as a basis for establishing management and development strategies so that they can be appropriately utilized (Rangkuti, 1997). The preparation of the strategy using internal and external matrices so that values (scores) will be obtained that will later be used as a basis in providing direction for the development of conservation based on local wisdom in the future.

Based on the results of the analysis can be known several factors that become a strength in the management of agricultural land based on local wisdom of the community, including (1) the availability of land resources; (2) local wisdom is still maintained and preserved; (3) the market potential of agricultural products is quite large; (4) The support of the village government is very large and (5) the experience of farming. Suppose management is focused on existing land resources while preserving local wisdom owned for the creation of environmental sustainability. In that case, production will increase and can meet market demand and have a positive impact on the socio-economic conditions of the community. While the factors that are weaknesses in the management of agricultural land based on local wisdom of the community include (1) the support of the district and central governments have not been seen; (2) the market price of agricultural products is unstable; (3) the absence of a long-term management plan at the farmer level; (4) the high dependence of farmers on steamers; (5) limited capital; and (6) lack of construction/counseling to farmers. Demand for vegetables and fruits is very high, but farmers do not get optimal profits due to unstable market prices and capital constraints. In addition, farmers also struggle to directly sell to consumers so that they have to pass through the collector, which means that farmer profits are reduced.

In line with research conducted by Situmorang and Simanjuntak (2015) related to the analysis of local wisdom in forest management by the community around the Sicike-Cike Natural Tourism Park (TWA) area of North Sumatera mentioned that the basic factors that affect the maintenance of local wisdom in the community are the form of gotong royong, kinship, adherence to indigenous figures and elements of trust in forest areas. The high level of local wisdom is supported by several things including low levels of education, homogeneity of the population and the least influence of modern culture in society (Situmorang and Simanjuntak, 2015).

Factors that become opportunities for local wisdom-based land management in Serang Village include (1) the attention of the district and central governments to the conservation of agricultural land based on local wisdom of the community; (2) the existence of supporting regulations related to local wisdom in environmental management; (3) the diversification and expansion of land; (4) involvement of farming groups in the management of agricultural land; (5) market demand increases; and (6) close marketing channels. These opportunities arise when land management is well done whose purpose is to conserve land with the application of local wisdom of the community.

Furthermore, for factors that are a threat in the management of agricultural land based on local wisdom of the community, among others (1) increasing the needs of farmers; (2) increasing demand for vegetables and fruit from steaming traders so as to encourage farmers to more intensely cultivate land; (3) pests and diseases that attack agricultural crops; (4) the low level of public education; (5) encroachment of forests into agriculture on sloping land; (6) high cost of farming; and (7) price games by collectors. These threats always accompany 
the management of agricultural land based on the local wisdom of the community. In fact, environmental management lies in two aspects, namely the orientation of economic aspects or the orientation of environmental aspects. If environmental management focuses on both aspects then the sustainable environment and the economy are also fulfilled. Still, if environmental management is only oriented to economic aspects, the economy will increase, but the environment is damaged and will later impact other aspects.

The preservation of local wisdom cannot run alone because it requires cooperation from all parties both communities, government and academia. Tamba (2020) explained that the supporting factors for the application of local wisdom include the factors of community support, government, the practice of tri hita karana philosophy and the operational foundation of "paras paros selulung subayantaka sarpanaya". As for the factors that inhibit local wisdom are economic, technological, institutional and physical barriers in society. So it is necessary to develop existing norms in society along with existing sanctions in relation to the preservation of local wisdom (Seprianto et al., 2017).

The results of the analysis showed that the total internal factor score of strength amounted to 3; and internal weakness factor of 2.3. As for external factors the odds have a total score of 2.6 and external factors the threat has a total score of 1.7. Based on the value of calculations, the strategic position of agricultural land conservation based on local wisdom is located in cell 1 with a coordinate value $(0.7 ; 0.9)$. The position of conservation of agricultural land based on local wisdom of the people of Serang Village is in cell 1, which shows that the right strategy to be applied is the SO (Strength-Opportunity) strategy in several ways as follows: 1. Preserve local wisdom owned by the community and applied in agricultural land management activities. Local wisdom owned by the people of Serang Village is an internal force and must be preserved. The village government, district government, and all community components are encouraged to participate in preserving local wisdom owned and applied in the conservation and management of agricultural land. This is believed to be able to have a positive impact on environmental sustainability and agricultural products.

2. Utilize assistance from the village, district, and central governments for the management and improvement of agricultural production. The people of Serang Village have an eye for sustainability as farmers both horticultural farmers and mixed gardens. The market potential of agricultural products is quite large supported by abundant land resources, but has not been developed optimally. It requires assistance from the village government, district government to the center in the management and increase of agricultural production. Furthermore, policies are also needed to stabilize agricultural commodity prices so that farmers are not harmed because of unstable prices.

3. Increase market distribution and take advantage of transportation access. Increasing market distribution is necessary to increase farmers' incomes. The addition of market distribution is one way to increase the sales agent of agricultural production in other areas. By increasing the distribution of the market, consumer demand will be met. Serang Village Government has Gapoktan Serang Sukses Makmur but has not been developed optimally. So far farmers are so dependent on steamers that they do not get optimal profits because the purchase price is relatively low. By increasing the distribution of the market, the marketing of agricultural products will be more widespread exceptionally if packaged with attractive packaging. In this case, all components' participation is needed to create economic and social welfare, cultural sustainability, and environmental sustainability.

4. Increase cultivated land with land available for increased agricultural production. Agricultural cultivation land in Serang Village is still relatively wide, moreover supported by market demand for high agricultural production so that there needs to be additional cultivated land. The addition of cultivated land still pays attention to aspects of conservation and sustainable environmental sustainability.

5. Maintain product quality and create customer satisfaction. Maintaining the quality of the wrong product aims to meet the needs of consumers and create customer satisfaction. Farmers produce superior quality products will be an attraction for consumers. High consumer satisfaction will continuously encourage consumption so that it will indirectly increase farmers' incomes. 
6. Cooperate with marketing channels to expand the market. Cooperate with marketing channels to expand the market. Cooperation on marketing channels aims to sell agricultural products out of a wider area. Farmers take advantage of the experience they have to manage agricultural land optimally so that the quality of production is good and production output increases so that it is ready to be sold to a broader area.

\section{CONCLUSION}

Conservation of agricultural land based on local wisdom practiced by farmers in managing agricultural land in Serang Village, among others, (1) pranoto mongso; (2) nyabuk gunung; (3) to tighten the water source (Festival of Tuk Sikopyah); (4) clearing agricultural land; (5) using traditional agricultural tools; and (6) Agroforestry. The community's highest and widely practiced conservation practice is using traditional agricultural tools by $99 \%$, hilling mountains and watering water sources by $96 \%$. As for conservation practices based on local wisdom that has rarely been done by the community, namely clearing agricultural land by $61 \%$. Some communities do not manage agricultural land because it meets market demand, so that agricultural land is managed intensely without any rest period to restore soil fertility. Based on the analysis, it is known that $34 \%$ of farmers in Serang Village fall into the category of not conservative, and $66 \%$ of farmers fall into the conservative category in managing their agricultural land based on the local wisdom of the community. Factors that affect the farming community to conduct the conservation of agricultural land based on local wisdom in Serang Village include (1) the age of farmers; (2) long farming; (3) education; and (4) land ownership. Based on multiple linear regression tests obtained the results of significance values for the influence of independent variables on dependent variables of $0.000<0.05$ and the value $\mathrm{F}$ calculated 8.173 greater than $\mathrm{F}$ table 2.698 so it can be concluded that there is a significant influence of independent variables (X) on dependent variables (Y). The coefficient of determination from this regression analysis is 0.256 , which means that variable $\mathrm{X}$ has an effect simultaneously on variable $\mathrm{Y}$ by $25.6 \%$. This clearly explains that the conservation of agricultural land based on local wisdom is influenced by several factors that simultaneously influence it.

Agriculture in Serang Village can be developed because it has extensive land resources and significant market demand. But it needs strategic and sustainable agricultural management (economic and environmental). Some of the appropriate agricultural land conservation strategies applied in the management of agricultural land in Serang Village include (1) preserving local wisdom owned by the community and applied in agricultural land management activities; (2) utilizing assistance from village, district and central governments for the management and improvement of agricultural production; (3) increase market distribution and take advantage of transportation access; (4) increase cultivated land with land available for increased agricultural production; (5) maintain the quality of the product and create consumer satisfaction; and (6) cooperation with the distribution channel to expand the market.

\section{REFERENCE}

Andri. 2012. Kelola Hutan Bersama Masyarakat [Internet]. [downloaded 2020 Jul 5]. Available on: www.aphi-pusat.net.

Aulia TOS, Dharmawan AH. 2010. Local wisdom in the management of water resources in Kuta Village. Sodality: Transdisciplinary Journal of Sociology, Communication, and Human Ecology. 4(3): 345-355.

Bakar A. 2011. Urban Sociology [Internet]. [downloaded 2020 Dec 12]. Available on: ebookbrowsee.com/buku-sosiologi-perkotaan-wahyu-a-bakar-pdf-d221361352.

Chasanah I, Purnomo PW, Haeruddin H. 2017. Analysis of the suitability of jodo beach tourism Sidorejo Village Gringsing Kebupaten Batang Subdistrict. Journal of Natural Resources and Environmental Management. 7(3): 235-243.

Hamidi. 2002. Kearifan Puak Melayu Riau Dalam Memelihara Lingkungan Hidup. Pekanbaru (ID): Riau Islamic University Press. 
Hilmanto R. 2009. Local Ecological Knowledge Dalam Teknik Pengelolaan Lahan Pada Sistem Agroforestry. Bandar Lampung (ID): Lampung University.

Martono N. 2010. Metode Penelitian Kuantitatif. Jakarta (ID): PT Raya Grafindo Persada.

Negara PD. 2011. Development of models of conservation of land and water resources in the framework of poverty alleviation. Scientific Solutions of Unsika Magazine. 10(20): 1-13.

Niman EM. 2019. Local wisdom and efforts to preserve the natural environment. Missio Journal of Education and Culture. 11(1): 91-106.

Nugraha RA, Makalew ADN, Syartinilia. 2020. The development plan of local wisdom-based tourist areas in the post mining area in Merawang District of Bangka Regency. Journal of Natural Resources and Environmental Management. 10(3): 374-389. doi: http://dx.doi.org/10.29244/jpsl.10.3.374-389.

Oktaviani T, Dharmawan AH. 2010. Local wisdom in the management of water resources in Kuta Village. Journal of Transdisciplinary Sociology, Communication and Human Ecology. 4(3): 344-355.

Rangkuti F. 1997. Analisis SWOT Teknik Membedah Kasus Bisnis. Jakarta (ID): PT Gramedia Pustaka Utama. Rangkuti F. 2006. Analisis SWOT Teknik Membedah Kasus Bisnis. Jakarta (ID): PT Gramedia Pustaka Utama.

Robinson P. 1997. Manajemen Stratejik Formulasi, Implementasi dan Pengendalian Jilid I. Jakarta (ID): Binarupa Aksara.

Sardjono MA. 1998. Community Empowerment Efforts Around Forest Areas in East Kalimantan.

Seprianto D, Suminar P, Nopianti H. 2017. Bukit larangan: principle of community conservation based on local wisdom (case study of Aur Gading Village Kerkap Subdistrict, North Bengkulu Regency). Journal of Sociology Nusantara. 3(2): 37-45.

Siswadi TT, Purnaweni H. 2011. Local wisdom in preserving springs (case study in Purwogondo Village, Boja Subdistrict, Kendal Regency). Journal of Environmental Sciences. 9(2): 63-68.

Situmorang ROP, Simanjuntak ER. 2015. Local wisdom of forest management by the community around the Sicike-Cike Natural Tourism Park area of North Sumatra. Widyariset. 18(1): 145-154.

Sumarni, Amirudin. 2014. Pengelolaan Lingkungan Berbasis Kearifan Lokal. Malang (ID): Aditya Median Publishing.

Sunderlin WD, Resosudarmo IAP. 1997. The rate and causes of deforestation in Indonesia: A review of confusion and its solutions. Occasional Paper. No. 9(1). ISSN 0854-9818. Bogor (ID): CIFOR.

Tamba IM. 2020. Contribution of local wisdom to critical land conservation. Agrimeta: Journal of Agriculture Based on Ecosystem Balance. 4(2): 1-15.

Thamrin H. 2013. The local wisdom in environmental sustainable. Kutub Khanah. 16(1): 46-59.

Wales HGQ. 1951. Greater India: A Study in South-East Asian Culture Change. London (GB): Bernard Quaritch LTD.

Yudana G, Aliyah I, Utomo RP. 2015. Management of Mount Lawu area with environmental insight and local wisdom in Karanganyar Regency. Conference on Urban Studies and Development; 2015 Sep 8. 119131.

Yunus R. 2012. Nilai-Nilai Kearifan Lokal (Local Genius) sebagai Penguat Karakter Bangsa: Studi Empiris Tentang Huyula. Yogyakarta (ID): CV. Budi Utama. 